\title{
Diagnostic and therapeutic laparoscopy in the horse: experiences in 236 cases
}

\author{
Astrid B.M. Rijkenhuizen and P. van Dijk \\ Universität Utrecht
}

\begin{abstract}
Summary
In the past decades the use of minimally invasive surgical techniques has increased dramatically in equine surgery. This report presents 236 cases in which the laparoscopic technique has been used for a variety of indications, both diagnostic and therapeutic. Diagnostic laparoscopy was performed in 26 cases. Indications were: recurrent colic (13), acute colic (1), suspected presence of an intra-abdominal tumour (3), suspected presence of adhesions (3), chronic weight loss (2), suspected presence of intra-abdominal abscesses (2) and to answer the question if an abdominal testicle was present or not (related to an insurance problem).

Therapeutic laparoscopy in standing position was performed for the following indications: castration of horses with normally descended testicles (66), abdominal cryptorchidism (68), inguinal cryptorchidism (52), ovary tumours (14), ovariectomy for other reasons (behavioural problems (6) and three to become a teasing mare). Under general anaesthesia dissection of adhesions discovered during diagnostic laparoscopy was performed in 5 horses, dissection of an ovary tumour tightly attached to the bladder in one horse and a traumatic ventral hernia was repaired in a foal with the implantation of a mesh.

In the experience of the author, the development of technical skills, the so-called learning curve for a specific laparoscopic intervention comprises about 30 patients.

It can be concluded that laparoscopy is a viable and very useful technique for both diagnostic and therapeutic procedures in the equine abdomen.
\end{abstract}

Keywords: laparoscopy, castration, ovarytumour, ovariectomy, horse, diagnostic laparoscopy, therapeutic laparoscopy

\begin{abstract}
Diagnostische und therapeutische Laparoskopie beim Pferd: Erfahrungen aus 236 Fällen
In den letzten Jahren hat die Anwendung minimalinvasiver Operationstechniken in der Pferdemedizin stark zugenommen. Der Artikel fasst die Erfahrungen aus 236 Fällen zusammen, in denen die laparoskopische Technik bei einer breiten Palette von Indikationen sowohl diagnostisch als auch therapeutisch zum Einsatz kam. Eine diagnostische Laparoskopie wurde in insgesamt 26 Fällen vorgenommen. Die Indikationen waren rezidivierende Kolik (13), akute Kolik (1), Verdacht auf abdominalen Tumor (3), Verdacht auf Adhäsionen (3), chronischer Gewichtsverlust (2), Verdacht auf Abdominalabszess (2) sowie in einem Fall zur versicherungstechnischen Klärung der Frage, ob ein abdominaler Hoden vorhanden war oder nicht. Eine therapeutische Laparoskopie am stehenden Pferd wurde mit folgenden Indikationen und Fallzahlen durchgeführt: Kastration von Pferden mit normalem Hodenabstieg (66), abdominaler Kryptorchismus (68), inguinaler Kryptorchismus (52), Ovartumor (14), Ovarektomie wegen Verhaltensänderung (6) und 3 Stuten sollten Probierstuten werden. Unter Allgemeinanästhesie wurden bei 5 Pferden Verwachsungen laparoskopisch gelöst, die zuvor bei einer diagnostischen Laparoskopie diagnostiziert worden waren. In einem Fall wurde eine Verwachsung zwischen Ovartumor und Blase gelöst und bei einem Fohlen wurde eine traumatisch bedingte ventrale Hernie durch laparoskopische Implantation eines Netzes operiert. Nach Erfahrung der Autorin bedarf es der Durchführung von ungefähr 30 laparoskopischen Eingriffen zur Entwicklung einer ausreichenden technischen Geschicklichkeit, die sog. Lernkurve des Chirurgen. Sie kommt zusammenfassend zu dem Schluss, dass die Laparoskopie eine praktische und sehr nützliche Technik für diagnostische und therapeutische Eingriffe am Abdomen des Pferdes darstellt.
\end{abstract}

Schlüsselwörter: Laparoskopie, Kastration, Ovariektomie, Ovariumtumor, Pferd, diagnostische Laparoskopie, therapeutische Laparoskopie

\section{Introduction}

In the past decades the use of minimally invasive surgical techniques has increased dramatically in equine surgery. From the early eighties onwards arthroscopic surgery has almost completely replaced conventional arthrotomies, which at present must be regarded as outdated for most indications (Mcllwraith 1984, Trotter and Mcllwraith 1996). Similarly, from the midnineties on the use of laparoscopy for abdominal surgical procedures has become increasingly popular (Fischer and Vachon 1992, Galuppo et al. 1996, Ragle et al. 1996, Bouré et al. 1997). Laparoscopy has been advocated for both diagnostic and therapeutic purposes. Indications for diagnostic laparoscopy include chronic colic and chronic weight loss, but the technique can also be used for taking biopsies (Walmsley 1999). Therapeutic applications of the technique are numerous. Laparoscopy has been used for adhesiolysis (Bleyaert et al. 1997), repair of ruptured bladders (Edwards et al. 1995), cystotomy, cryptorchidectomy (Wilson et al. 1996, Davis 1997, Hendrickson and Wilson 1997, Ragle et al. 1998, Rijkenhuizen 1999), castration of the normal stallion (Wilson et al. 1996, Rijkenhuizen 1999), bleeding after castration (Rijkenhuizen 2001), diaphragmatic hernias, inguinal hernias (Fischer et al. 1995, Klohnen and Wilson 1996), colopexy (Trostle et al. 1996), ovariectomy (Palmer 1993, Bouré et al. 1997, Gottschalk and van den Berg 1997, Hanson and Galuppo 1999), resection of umbilical structures (Fischer 1999) repair of rectal tears, and surgical embryo transfer.

Laparoscopic surgery is reported to have various advantages over conventional surgery. In some cases the use of laparoscopic techniques makes the surgical procedure less complicated, as in the case of abdominal cryptorchids where the localisation 
of the abdominal testicle is much easier accomplished than in the classic approach. Additionally, some intra-abdominal conditions can be better visualised using laparoscopic techniques than with conventional surgery. A number of conditions in the dorsal abdomen, such as duodenitis or necrosis of the descending colon as a result of a rectal tear, are very difficult to diagnose without laparoscopy (Göbel and Koene 1995, Galuppo et al. 1995, Ragle et al. 1997). Intra-operatively haemostasis can be very adequately controlled and the procedure is rather quick once the surgeon is experienced enough. Additionally, as the technique is minimally invasive, the post-operative complication rate is lower than with conventional surgery and the average hospital stay and the time to full return to normal activity is considerably reduced (Bouré et al. 1997). The fact that it is not possible to visualise the entire abdomen using one single portal has to be looked at as a limitation of the procedure. If all parts of the abdomen have to be explored, several portals and various positions of the horse are necessary. The overall sensitivity of diagnostic laparoscopy (75\%) is considered reasonable, but is still thought insufficient to use the technique as a single means for the confirmation of the absence of abnormalities (Walmsley 1999). Another disadvantage of the technique is the need for expensive equipment and the rather long learning period that is necessary to gain enough experience.

Thus far, literature data focus to a large extent on one single application of the technique, be it therapeutic or diagnostic. Additionally, reports generally contain relatively low numbers of cases. This report presents a series of 236 cases in which the technique has been used for a variety of indications, both diagnostic and therapeutic. After a brief description of the techniques used, attention is focused on the success (or failure) rate and on the occurrence of complications. Also, aspects associated with the development of technical skills, the so-called "learning curve", are discussed with the aim to come to a balanced assessment of the usefulness of various applications of the technique in today's equine surgery.

\section{Materials and methods}

\section{Laparoscopic equipment and general procedures}

For all procedures described in this study a rigid laparoscope (diameter $10 \mathrm{~mm}$, length $57 \mathrm{~cm}$, angle either straight forward $0^{\circ}$ or $30^{\circ}$ ) connected to a videocamera was used. The laparoscope was guided into the abdominal cavity through a $10 \mathrm{~mm}$ trocar. Trocars of five $\mathrm{mm}$ diameter were used for the introduction of the surgical instruments (biopsy forceps, biopsy needles, needles, needle holders, scissors, grasping forceps, probes, push-rods, etc.). Distension of the abdomen was obtained using a carbon dioxide $\left(\mathrm{CO}_{2}\right)$-insufflator' (standard flow-rate 7-8L/ min, maximum flow-rate $9.9 \mathrm{~L} / \mathrm{min}$ ) until a maximal intra-abdominal pressure of $6 \mathrm{~mm} \mathrm{Hg}$ was reached in standing horses. In horses under general anaesthesia higher pressures, up to 20 $\mathrm{mm} \mathrm{Hg}$, were used. To prevent bacterial infection of the abdomen a 0.2 micron $\mathrm{CO}_{2}$ gas filter ${ }^{2}$ was placed between the pump and the trocar.

Before surgery, the patients were fastened for 36 hours to allow a better visualisation (less gas in the gastrointestinal tract) and to reduce the risks of perforation of abdominal organs. Tetanus prophylaxis was provided. For the standing procedure the horses were restrained in stocks with the tail tied up and sedated with detomidine ${ }^{3}(1 \mathrm{mg} / 100 \mathrm{~kg}$ BWT intravenously), together with buprenorphine ${ }^{4}(0.6 \mathrm{mg} / 100 \mathrm{~kg}$ BWT intravenously). Sedation was maintained with a continuous drip infusion of detomidine $(0.1 \mu \mathrm{g} / \mathrm{kg} / \mathrm{min}$ intravenously) (van Dijk et al. in press). The surgical sites were prepared for aseptic surgery in routine fashion. At the sites of the portals, the skin was locally infiltrated with lidocain hydrochloride $2 \% 5$.

In the standing horse, the portal for the laparoscope was located in most cases just dorsal to the crus of the internal oblique abdominal muscle and $2 \mathrm{~cm}$ caudal to the last rib. In some cases the size of the paralumbar region made it necessary to make the portal at the same height, but between the last two ribs. The instrumental portals were placed more caudally and ventrally, depending on the procedure performed. In horses under general anaesthesia the location of the laparoscopic portal varied depending on the indication. In these horses, visualisation of the caudal part of the abdomen could be improved by using the Trendelenburg position (lifting the caudal part of the operating table). For better inspection of the cranial part the reversed Trendelenburg position was used. Also the backside or ventral side of the horse may be elevated in order to inspect the dorsal part or ventral part of the abdomen.

After surgery, the insertion portals were closed in one or two layers (polyglactin USP 2-06).

\section{Clinical cases}

Diagnostic laparoscopy was performed in 26 cases. Indications were: recurrent colic (13), acute colic (1), suspected presence of an intra-abdominal tumour (3), suspected presence of adhesions (3), chronic weight loss (2), suspected presence of intra-abdominal abscesses (2) and to answer the question if an abdominal testicle was present or not (related to an insurance problem) (Figs 1, 2 and 3).

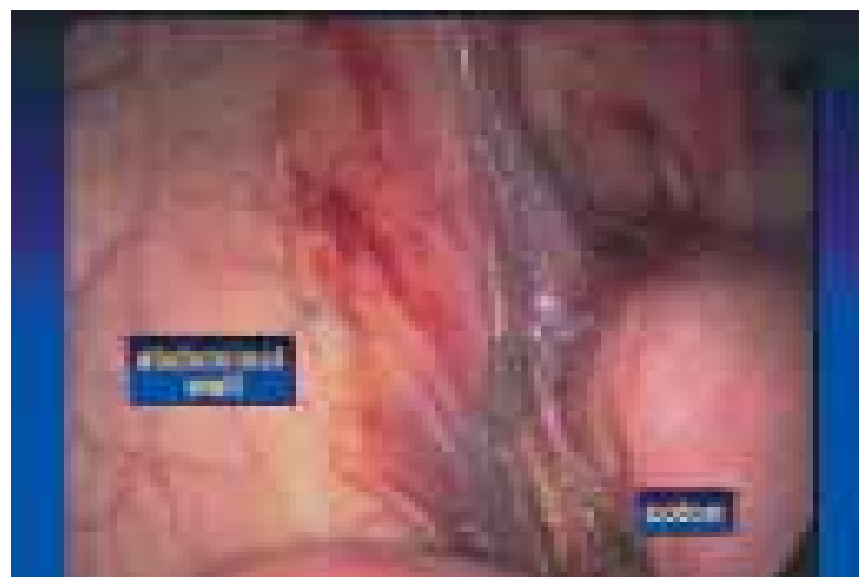

Fig 1: Adhesion of the left dorsal colon to the abdominal wall diagnosed in a standing horse.

Verwachsung von rechtem dorsalem Kolon mit der Bauchwand. Laparoskopie am stehenden Pferd.

Therapeutic laparoscopy in standing position was performed for the following indications: castration of horses with normally descended testicles (66), abdominal cryptorchidism (68), inguinal cryptorchidism (52), ovary tumours (14), ovariectomy for other reasons (behavioural problems (6) and three as a teasing mare). Under general anaesthesia dissection of adhesions discovered during diagnostic laparoscopy was performed in 4 horses, dissection of an ovary tumour tightly attached to the bladder in one horse and a traumatic ventral hernia was repaired in a foal with the implantation of a mesh. 


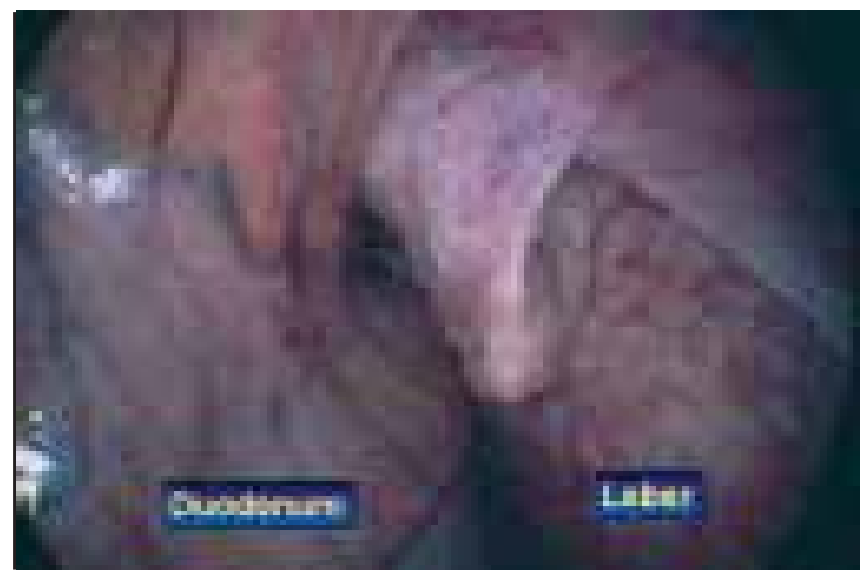

Fig. 2: Laparoscopic view of the left dorsal abdominal cavity of a patient with complaints of chronic weight loss due to liver cirrhosis.

Laparoskopischer Blick in die linke dorsale Bauchhöhle eines Patienten mit chronischem Gewichtsverlust im Verlauf einer Leberzirrhose.

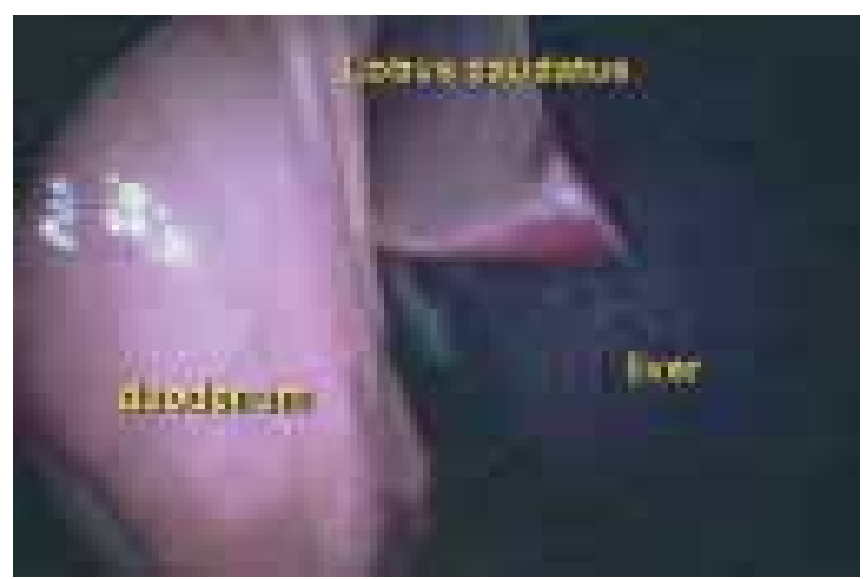

Fig. 3: Laparoscopic view of the liver in the standing horse.

Laparoskopische Ansicht der Leber am stehenden Pferd

Specific surgical techniques

\section{Diagnostic laparoscopy}

Diagnostic laparoscopy was performed in 23 cases in the standing position and in 3 cases under general anaesthesia: 2 in lateral recumbence with a flank approach and 1 in dorsal recumbence with a ventral approach. The abdomen was examined on one or both sides depending on the indication. An instrument portal was made for instrumental palpation and manipulation of the bowel. In one case a biopsy of the jejunum was obtained by introducing an intestinal clamp through the instrumental portal to grasp the jejunum. After removal of the trocar and enlargement of the instrument portal the part of the jejunum could be exteriorised to take the biopsy. In 5 cases adhesions were encountered. Adhesiolysis was performed in standing position in one animal, in the other 4 cases the horse was positioned in lateral recumbence using the Trendelenburg position. The adhesions were dissected with $5 \mathrm{~mm}$ scissors connected to the electro-cauter ${ }^{7}$ (Ellman Surgitron, 100Watt). Postoperatively antibiotics were continued for 5 days.

Castration of male horses with normally descended testicles (and inguinal cryptorchidy)

The technique for this procedure was modified various times, as the first results were disappointing. The first procedure con- sisted of the placement of a ligature (polyglactin 910, USP2) around the spermatic cord near the vaginal ring. To achieve this, the mesorchium was locally anaesthetised and then perforated. A ligature was inserted through this perforation and positioned above the bladder. The ligature was picked up with the forceps on the mediocaudal side of the spermatic cord and retracted extra-corporally (Fig 4). A modified "Roeders knot"

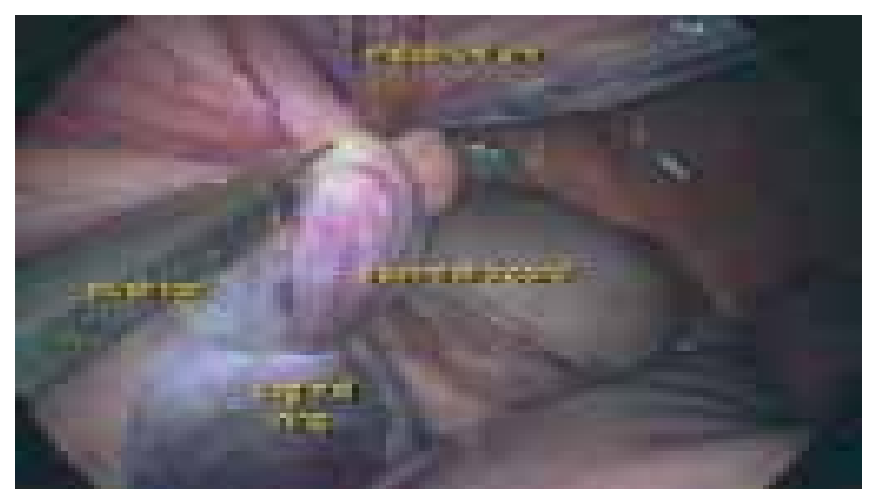

Fig. 4: Laparoscopic view of the right part of abdominal cavity. A ligature is positioned around the spermatic cord.

Laparoskopischer Blick in die rechte Abteilung der Bauchhöhle. Um den Samenstrang liegt eine Ligatur

was tied and the slipknot advanced with a push-rod, while pulling the long tail of the ligature, and tightened. The suture was cut adjacent to the knot. The mesorchium was ligated twice and the testicle remained in place. Initially, no attention was paid whether the ductus deferens was included in the ligature or not. Later, care was taken to always include this structure in the ligature. In the actual version of the technique, both the ductus deferens and the blood vessels are cut with laparoscopic scissors $\left(5 \mathrm{~mm}\right.$ scissors ${ }^{1}$ or $10 \mathrm{~mm}$ scissors $\left.{ }^{8}\right)$ in a way that the distal part of the spermatic cord retracts into the inguinal canal (Fig 5 and 6).

\section{Abdominal cryptorchidy}

As the testicle is located in the abdomen, there is no need to perforate the mesorchium (Fig 7). These cases were treated by placing two ligatures around the mesorchium in the same way as described above.

\section{Ovariectomy}

The laparoscope and instrument trocars (one $5 \mathrm{~mm}$ and one $10 \mathrm{~mm}$ ) were introduced in the paralumbar region as described. The mesovarium and proper ligament were locally anaesthetised with $10 \mathrm{ml}$ of $2 \%$ lidocaine hydrochloride and perforated with $5 \mathrm{~mm}$ scissors', just caudal to the ovarian artery. Through these perforations the mesovarium and the proper ligament were ligated using polyglactin 910 (USP2) (Fig. 8 and 9). Subsequently, the ovary was dissected with 5 $\mathrm{mm}$ scissors ${ }^{1}$ or $10 \mathrm{~mm}$ scissors ${ }^{8}$, while holding it with a 10 $\mathrm{mm}$ grasping forceps. The incisions of the two instrumental portals were connected and the ovary removed through this enlarged incision (average 6-8 cm). The same procedure was repeated at the other side. In one case both ovaries were reduced in size with scissors prior to removal, and the small parts were removed through a $10 \mathrm{~mm}$ trocar. Antibiotic was administered pre-operatively (trimethoprim sulfadioxine?, 30 $\mathrm{mg} / \mathrm{kg}$, intravenously). 

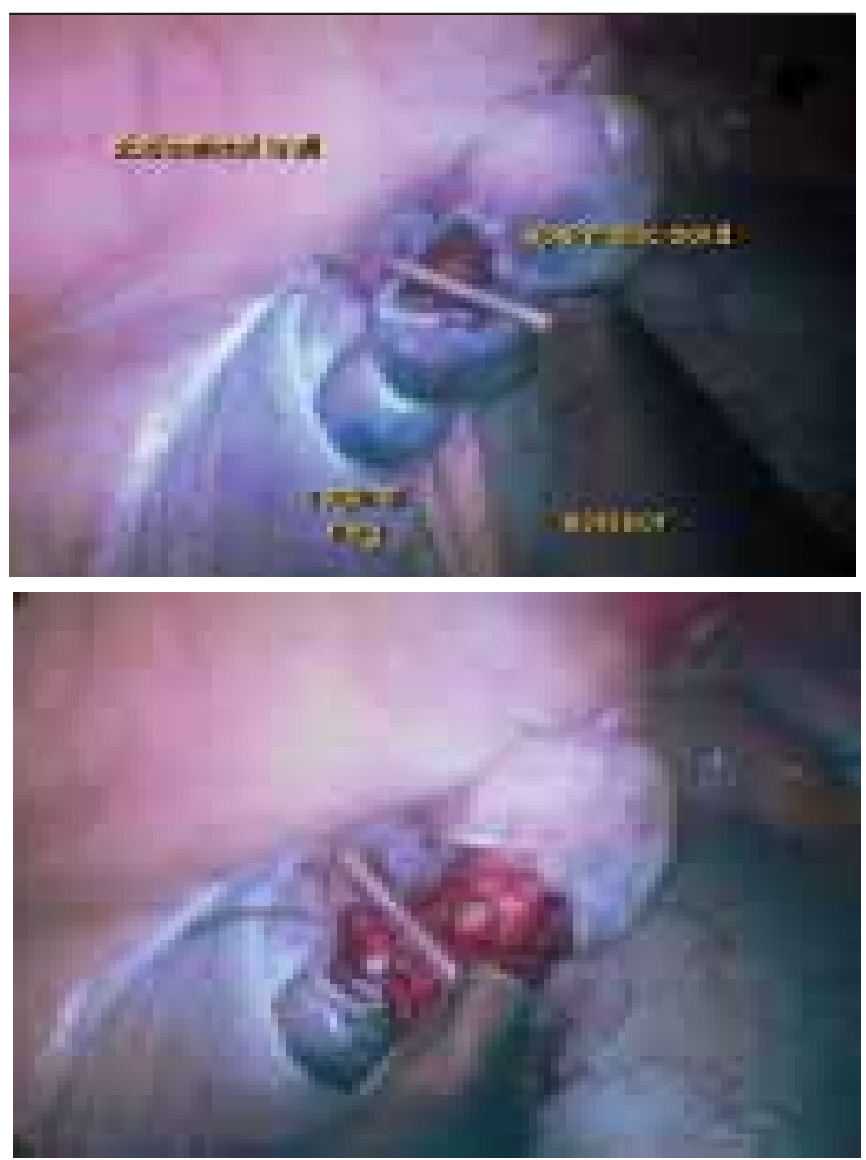

Fig. 5 and 6: Laparoscopic view of the cutting of the spermatic cord. Transsektion des Samenstrangs

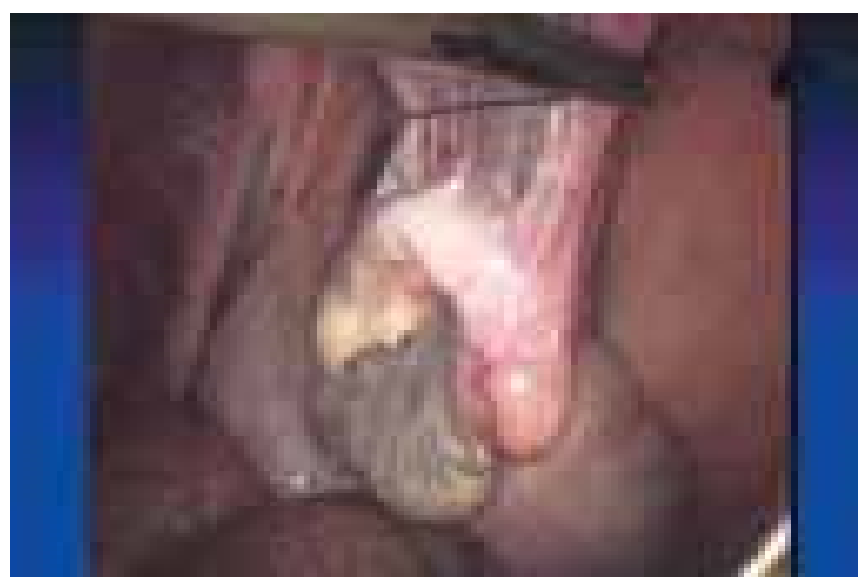

Fig. 7: Laparoscopic view of an abdominal testicle on the right site of the abdominal cavity. A ligature is positioned around the mesorchium.

Abdominaler Hoden in der rechten Bauchhöhle. Um das Mesorchium liegt eine Ligatur

\section{Ovary tumours}

The procedure was identical to the one described for ovariectomy. However, the incision for removal of the tissue had to be larger. In case the presence of cysts had been demonstrated by the pre-operative ultrasonographic examination, the cysts were punctured intra-operatively and emptied by suction. In all cases with ovary tumours, antibiotics were administered pre- and post-operatively (trimethoprim sulfadioxine $(30 \mathrm{mg} / \mathrm{kg}$, intravenously) pre-operatively and trimetoprim sulfadiazine ${ }^{10}(30 \mathrm{mg} /$ $\mathrm{kg}$ twice daily orally) post-operatively for three days).

\section{Results}

\section{Diagnostic laparoscopy}

The indications, the findings at laparoscopy, and the post-operative outcome of all cases that underwent diagnostic laparoscopy are listed in Table 1. In 17 cases a definitive diagnosis could be made with the help of this minimal invasive technique. In some cases of recurrent colic no abnormalities were encountered. In the case in which the presence of abdominal testicles was disputed, a clear and definitive answer could be given and if necessary, castration was performed.

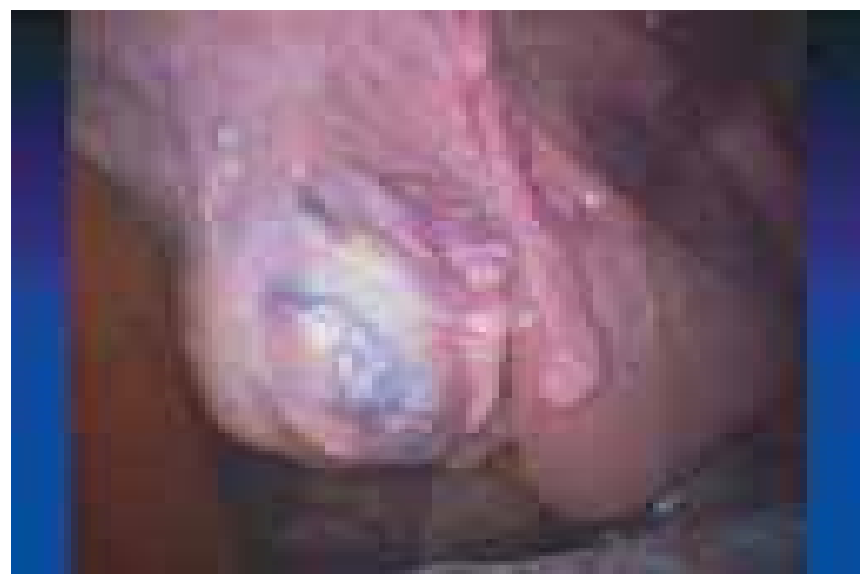

Fig. 8: Laparoscopic view of a right ovary.

Laparoskopische Ansicht des rechten Ovars

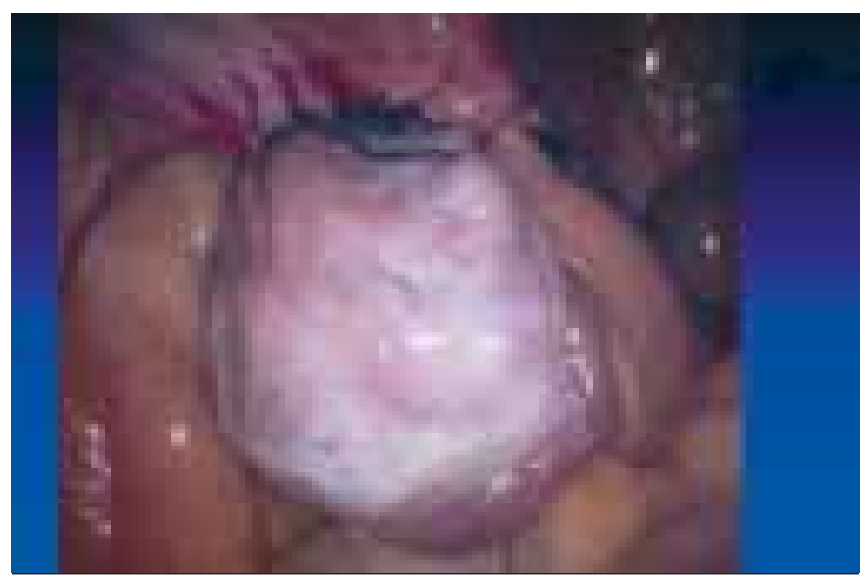

Fig. 9: Laparoscopic view of a right ovary. A ligature is positioned around the mesovarium

Laparoskopischer Blick auf ein rechtes Ovar. Um das Mesovarium liegt eine Ligatur

\section{Therapeutic laparoscopy}

Castration of male horses with normally descended testicles (and inguinal cryptorchidy)

The success rate of the initially employed technique was disappointing as many horses (63\%) continued to produce testosterone at a level above measurable values, indicating that there was still viable testicular tissue present (Table 2). After the introduction of the technique in which it was made sure that the ductus deferens was transected in all cases, the success rate rose to $79 \%$, which is still well below that of the standard castration procedures using open surgery. The last change in the tech- 
Tab. 1: Patients operated on for diagnostic laparoscopy, the laparoscopic findings and the post-operative results. The diagnostic laparoscopy was performed in the standing horse unless differently mentioned.

Indikationen, laparoskopische Befunde und postoperative Ergebnisse. Laparoskopie am stehenden Pferd wenn nicht anders angegeben.

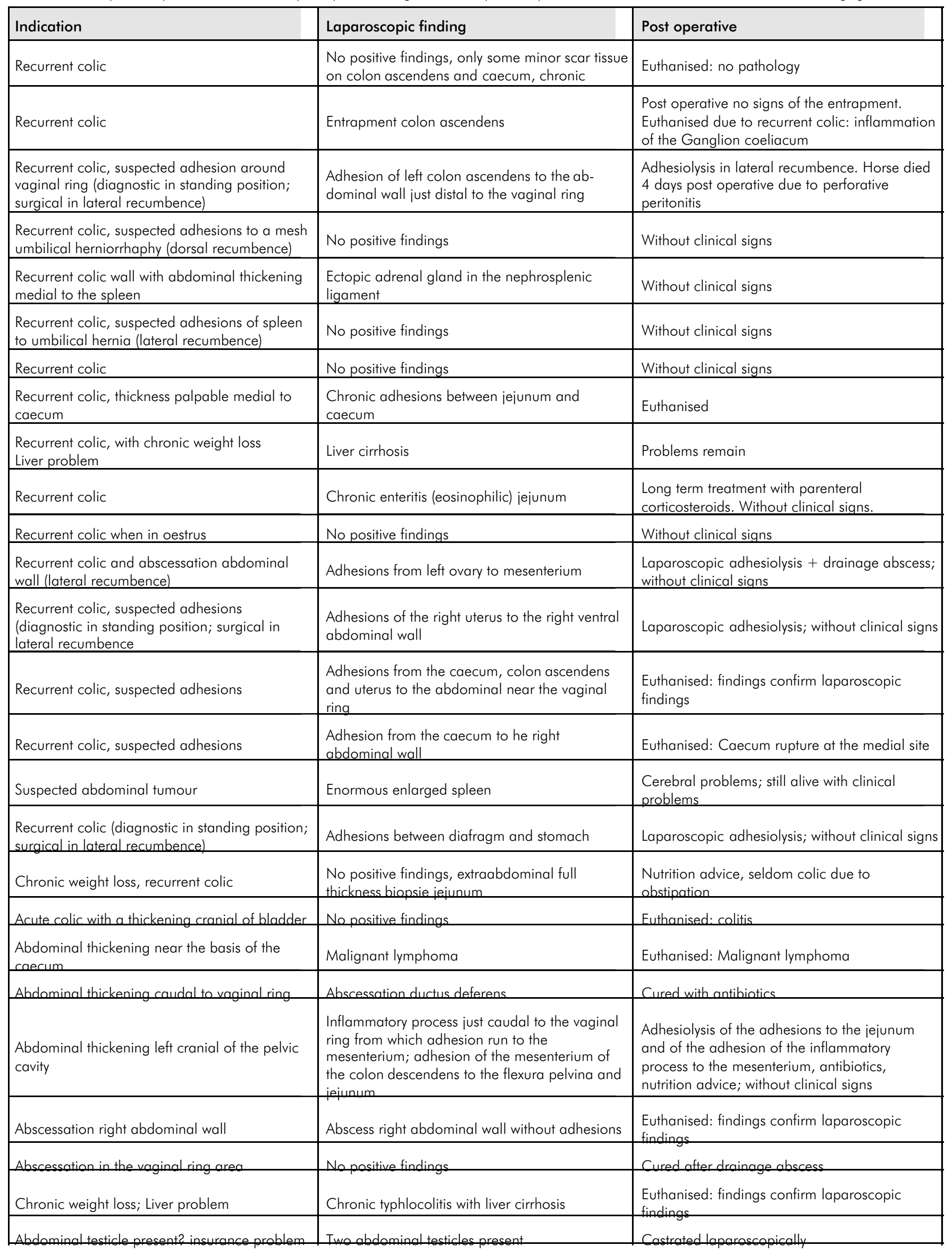


nique (not only ligating, but also cutting all constituents of the spermatic cord), made this figure rise to $96 \%$.

Post-operatively slight to mild oedema of the scrotal tissue was noticed in $30 \%$ of the cases. This figure was slightly higher (32\%) in the horses in which the spermatic cord was cut. Only in one horse the post-operative oedema had to be classified as severe. However, in this case the condition resolved within a week without intervention.

A rise in rectal temperature was seen in $39 \%$ of the animals (average $38.8^{\circ} \mathrm{C}$, range $38.1-41.1^{\circ} \mathrm{C}$ ). In most of these cases $(81 \%)$ the elevated temperature lasted for only one day; in the remaining $19 \%$ it took 2-5 days before the temperature returned to normal. These horses were treated with NSAID's (phenylbutazone ${ }^{11}, 4.4 \mathrm{mg} / \mathrm{kg}$ BWT orally, every 12 hours, or vedaprofen ${ }^{12}$, starting-dosage $2 \mathrm{mg} / \mathrm{kg}$, followed by $1 \mathrm{mg} / \mathrm{kg}$ twice daily orally).

Three horses $(2 \%)$ developed a wound infection at one of the portals and in one case an infection of the intra-abdominal part of the ductus deferens was seen which had to be treated with antibiotics for a prolonged period.

\section{Ovariectomy}

In all cases removal of the ovaries was successful and could be carried out without major problems. Bleeding of the stump was seen in one case which could easily be solved by ligating the bleeding vessel. In one case bleeding from the abdominal wall was encountered, which was treated in a similar way. Three mares showed a rise in rectal temperature the day after surgery (two mares $38.2^{\circ} \mathrm{C}$ and one mare $40.3^{\circ} \mathrm{C}$ ). Two mares were mildly depressed with reduced appetite, and two mares showed abdominal discomfort the day after surgery. In these cases NSAID's (vedaprofen or flunixin meglumine ${ }^{13}$ $1 \mathrm{mg} / \mathrm{kg}$ intravenously) were administered for 2 to 14 days. Incisional healing was per primam in eight mares, in the remaining case wound infection of the enlarged incision occurred on both sides.

The first two mares were operated on two separate occasions (one side each day) with a surgery time of 90 minutes per session. In all other mares both sides were operated on the same occasion. Surgical time for bilateral ovariectomy decreased from 160 minutes for the first surgery to 60 minutes for the last mare.

\section{Ovary tumours}

The extirpated tumours had an average diameter of 12-15 cm. There appeared to be 11 granulosa cell tumours and 3 cystic ovaries. Two cystic ovaries were punctured intra-operatively and emptied by suction. In one case $500 \mathrm{ml}$ was removed, in the other one $250 \mathrm{ml}$. No bleeding of the stump was observed during or after the operation. In one case haemorrhage from the abdominal wall occurred; the vessel involved was successfully ligated. Surgery time decreased during the series from 120 minutes to 45 minutes.

Post-operatively, five mares showed abdominal discomfort (and reduced appetite). These animals were again treated with NSAID's and recovered uneventfully. An increase in rectal temperature was noted in 5 mares (average $38.6^{\circ} \mathrm{C}$ ). Incisional healing was per primam in 11 mares. In 2 mares seroma formation occurred which was treated by puncture, suction and locally applied corticosteroids (dexamethason natriumfosfaat 4 $\mathrm{mg})^{14}$. In the remaining mare dehiscence of the enlarged inci- sion in one flank occurred after removal of the sutures nine days after surgery. The wound was debrided and closed and healed by primary intention.

Complications not related to the specific intervention

Equipment-related complications that occurred included problems with the optic cable, and breakage of instruments. Other problems included a decrease in light intensity because of intra-operative haemorrhage caused by puncture of the spleen with the trocar (in 5 cases), or bleeding from the abdominal wall (one case). The degree of haemorrhage following puncture of the spleen was limited and did not prohibit the surgical procedure.

Perforation of a part of the gastrointestinal tract occurred in two cases. In one case the left dorsal ascending colon was involved and in the other case the caecum. In the first case the laparoscope was left in place while the incision was enlarged at the ventral wound edge until it was possible to pass a hand into the abdomen. The colon including the laparoscope was grasped and withdrawn through the incision. The laparoscope was removed from the colon and the perforation (size about $1 \mathrm{~cm}$ ) was sutured in two layers. Wound healing was per primam and no adhesions developed. In the other case the caecum was perforated. The perforation was laparoscopically closed with staples ${ }^{15}$. Unfortunately, a second perforation stayed unnoticed and the pony died as a result of the ensuing peritonitis. Minor complications occurred in some of the first cases because of inexperience of the surgeon. These complications included fogging of the laparoscope and not penetrating the peritoneum while inserting the trocar, resulting in insufflation of the subcutaneous tissue instead of the abdominal cavity. These complications resulted in an increase in surgical time, but had no serious consequences.

Tab. 2: The number of horses castrated and the results of succesful castration, defined by a testosteron level below the measurable values

Anzahl kastrierter Pferde und die Ergebnisse erfolgreicher Kastration definiert durch Testosteronwerte unterhalb der Messgrenze.

\begin{tabular}{|c|c|c|c|c|c|c|}
\hline & \multicolumn{2}{|c|}{$\begin{array}{c}\text { Castration } \\
\text { (initial } \\
\text { technique) } \\
\text { modification } \\
\text { (including } \\
\text { ductus } \\
\text { deferens) }\end{array}$} & \multicolumn{2}{|c|}{$\begin{array}{c}\text { 2nd } \\
\text { modification } \\
\text { (transection of } \\
\text { whole } \\
\text { spermatic cord) }\end{array}$} \\
\hline N & $\begin{array}{c}\text { Success } \\
\text { rate }\end{array}$ & $\mathrm{N}$ & $\begin{array}{c}\text { Success } \\
\text { rate }\end{array}$ & $\mathrm{N}$ & $\begin{array}{c}\text { Success } \\
\text { rate }\end{array}$ \\
\hline $\begin{array}{c}2 \text { descended } \\
\text { testicles }\end{array}$ & 28 & $16(57 \%)$ & 25 & $19(76 \%)$ & 13 & $13(100 \%)$ \\
\hline Inguinal & 25 & $13(52 \%)$ & 8 & $6(75 \%)$ & 19 & $17(90 \%)$ \\
\hline Unilateral & 23 & $11(48 \%)$ & 8 & $6(75 \%)$ & 16 & $14(88 \%)$ \\
\hline Bilateral & 2 & $2(100 \%)$ & - & - & 3 & $3(100 \%)$ \\
\hline abdominal & 30 & $26(87 \%)$ & 14 & $11(79 \%)$ & 24 & $24(100 \%)$ \\
\hline Unilateral & 23 & $19(83 \%)$ & 8 & $5(63 \%)$ & 13 & $13(100 \%)$ \\
\hline $\begin{array}{c}\text { Unilateral, } \\
\text { other site } \\
\text { castrated }\end{array}$ & 5 & $5(100 \%)$ & 1 & $1(100 \%)$ & 8 & $8(100 \%)$ \\
\hline Bilateral & 2 & $2(100 \%)$ & 5 & $5(100 \%)$ & 3 & $3(100 \%)$ \\
\hline Total & 83 & $57(63 \%)$ & 47 & $37(79 \%)$ & 56 & $54(96 \%)$ \\
\hline
\end{tabular}




\section{Discussion}

The introduction of laparoscopy was without any doubt one of the most exciting events in equine surgery in recent years. Laparoscopy offers a good visualisation of the contents of the dorsal abdomen in the normal, standing position. The other parts of the abdomen can be visualised equally well, but in these cases the horse has to be positioned in dorsal or lateral recumbence under general anaesthesia. The technique permits access to areas that are difficult to reach by laparotomy and offers the possibility for quite extensive surgical interventions which makes laparoscopy of great potential significance for both diagnostic and therapeutic purposes. However, there are also some drawbacks. Though laparoscopy is a minimally invasive technique, complications may occur. Some of these can be severe. Further, like with arthroscopy, experience may be even more important than with conventional surgery. This may lead to long learning curves and the need for relatively large case loads to maintain surgical experience. Advantages and disadvantages of the technique will be discussed against the background of the case series presented in this paper.

The majority of the laparoscopic procedures were performed in the standing horse. Laparoscopy in this position offers excellent visualisation of the caudal aspect of the liver, pancreas, epiploic foramen, duodenum, (parts of the) jejenum, ileum (occasionally), caecum, pelvic flexure of the large colon, other parts of the ascending colon and descending colon, spleen, nephrosplenic ligament, kidneys, bladder, ovaries, uterus and vaginal ring with the spermatic cord. In general, the square standing position is the best for good visualisation of these structures. The horse may also lean a little away from the surgeon, but leaning towards the surgeon impairs visualisation. For some procedures anatomic constraints imply that the horse has to be under general anaesthesia which obviously takes away one of the great advantages of the technique. Results of diagnostic laparoscopy were encouraging as a definitive diagnosis could be made in the majority of the cases. In some of these the diagnosis could not have been made without this technique. Experience proved to be crucial. This became most evident in the normal males that were castrated. The initially employed technique proved to be insufficiently effective as many horses continued to produce testosterone. The success rate improved considerably after the first adaptation of the technique, but did not reach acceptable levels until the second modification that consisted of cutting the entire spermatic cord. The only two failures with this technique occurred in the first 6 cases. After these, no failures have occurred. Interestingly, double ligation of the cord, without cutting it, proved to be effective enough in abdominal cryptorchids, but not in males with normally descended testicles.

Experience was also crucial in relation to some complications not associated with a specific surgical intervention, but with the technique in general. Fogging of the laparoscope for instance can severely impair vision and hence prolong surgery time. It can, however, easily be avoided by using a defogging agent or by immersing the laparoscope in warm saline for 15 minutes before entering the abdomen, as fogging of the lense is caused by the temperature difference between the instrument and the abdominal contents. Fogging can also be caused by cooling as a result of the insufflated $\mathrm{CO}_{2}$ and is then best removed by wiping the tip of the laparoscope over the bowel surface (not over the omentum or fatty structures). Insufflation of the subcutaneous tissues because of a failure to penetrate the perito- neum when placing the trocar is another common error that disappears as experience increases.

Obviously, the learning curve was reflected in surgery time. In general, the mean operating-room time (which includes preparation of the patient) fell nearly $20 \%$ over all laparoscopic procedures (from 137 to 112 minutes). It should be realised that this time includes time for teaching of students and residents. For some common procedures operation time was approximately halved, as in the case of bilateral castration where a reduction from 87 to 45 minutes was realised and for bilateral ovariectomy where surgery time fell from 160 to 60 minutes. In the experience of the author, it takes about 30 patients to master a specific laparoscopic intervention.

Many complications of laparoscopic surgery have been described. These include incisional herniation (Plaus 1993), perforation of viscera or perforation of the spleen while introducing the trocar in the abdominal cavity (Fischer 1991, Embertson and Bramlage 1992), post-operative peritonitis (Fischer et al 1986), adhesion-formation (Tulandi 1997), wound infection, abdominal wall bleeding (Ragle et al. 1998) and inadvertent ligation of the ureter (Huskamp 1999 personal communication). Taking into account the localisation of the portals, hernia formation after laparoscopic procedures may be mainly a theoretical risk in horses. It was not seen by the author. Perforation of the gastrointestinal tract occurred in two cases, one of which appeared to be fatal. Puncture of the spleen occurred in 5 cases, but did not substantially impair the surgical intervention. Bleeding from the abdominal wall, as a result of trocar placement or enlargement of the incision, was noticed in four cases. The resulting haemorrhage increased surgery time, but did not cause haematoma formation as described by Ragle et al. (1998). These complications may, in part, also have been prompted by inexperience of the surgeon, as all perforations of the spleen and/or viscera occurred in the first group of 55 patients.

A remarkable post-operative finding was the elevation of body temperature during the first 2 days after surgery. This phenomenon is probably caused by a chemical peritonitis as a reaction to the $\mathrm{CO}_{2}$ which is converted into carbonic acid that may irritate the peritoneum (Jones 1990). The $\mathrm{CO}_{2}$ is also considered responsible for the occurrence of abdominal pain observed in horses after laparoscopy (Fischer et al. 1986, Bouré et al. 1997). Air may be an alternative, but has the risk of air embolus formation (Jones 1990). Nitrous gas is another possibility, but can not be used in combination with electro-coagulation.

The incidence of post-operative infection was less than in conventional surgery and post-operative recovery was quicker. Only $5(2 \%)$ portal wounds ( 3 instrumental portals and 2 enlarged incision for the ovariectomy) in 236 patients became infected. One horse developed an infection of the ductus deferens inside the abdomen. The incidence of portal wound infection did not vary during the period of laparoscopy and was not affected by a learning curve. Figures are much more favourable than in many classic techniques. It has been reported that, when using the half-closed castration method, $9.1 \%$ of the horses develop a chronic purulent funiculitis that has to be treated surgically (Rutgers and Merkens 1983). The overall incidence of postoperative wound infection was still higher in that study. It can be concluded that laparoscopy is a viable and very useful technique for both diagnostic and therapeutic procedures in the equine abdomen. Its advantages are many and, for a large number of indications, outnumber the disadvantages. The equine surgeon who wants to take up this technique should realise 
that, apart from large investments in expensive equipment, one should take into account that it takes a considerable amount of patients to gain enough experience. It also requires a certain number of cases on a regular basis to maintain this experience at an acceptable level. The potential case load in a specific clinic should, therefore, be high enough to warrant the necessary investments in time and money.

There is no doubt that laparoscopy in those clinics that meet the requirements outlined above will have its fixed place in the array of surgical options. For a number of indications it will replace and outdate the classic open approach, not unlike arthroscopy has replaced and outdated arthrotomy for many indications.

\section{Manufacturers' addresses:}

1 Storz ${ }^{\circledR} \mathrm{GmbH} \&$ Co. Tuttlingen, Germany.

2 CO 2Guard ${ }^{\circledR}$, allied Healthcare Products inc., St. Louis MO631 10

3 Domosedan $^{\circledR}$, Pfizer Animal Health BV Capelle aan de IJssel, the Netherlands.

${ }^{4}$ Temgesic $^{\circledR}$, Schering-Plough, Maarssen, the Netherlands.

5 Alfacain $2 \%$ and Adrenaline, Alfasan, Woerden, the Netherlands.

6 Vicry ${ }^{\circledR}$, Ethicon, Johnson \& Johson, Amersfoort, the Netherlands.

7 Ellmann Surgitron ${ }^{\circledR}$, InstruVet CV Industrieweg-Noord 6c 3958 VT Amerongen

8 Dr.Fritz $^{\circledR}$ Endoskopie- \& Dokumentations-Systeme, Tuttlingen, Germany.

9 Borgal 24\% ${ }^{\circledR}$, Hoechst Roussel Vet, Brussel, Belgium.

10 Equitrim $^{\circledR}$, AUV Coöperatie, Cuijk, the Netherlands.

${ }^{11}$ Prodynam ${ }^{\circledR}$, Leo Pharmaceuticals, Weesp, the Netherlands.

${ }_{12}$ Quadrisol $^{\circledR}$, Intervet, Boxmeer, the Netherlands.

13 Finadyne ${ }^{\circledR}$, Schering-Plough, Maarssen, the Netherlands.

${ }^{14}$ Dexadreson, Intervet, Boxmeer, the Netherlands.

${ }^{15}$ Endopath ${ }^{\circledR}$ EMS endoscopic multifeed Stapler, Ethicon, Johnson \& Johson, Amersfoort, the Netherlands.

\section{References}

Bleyaert H.F., M.P. Brown, G. Bonenclark and J.E. Bailey (1997): Laparoscopic adhesiolysis in a horse. Vet Surg 26, 492-6.

Bouré L., M. Marcoux and S. Laverty (1997): Laparoscopic abdominal anatomy of foals positioned in dorsal recumbency. Vet Surg ,26, 1-6.

Bouré L., M. Marcoux and S. Laverty (1997): Paralumbar fossa laparoscopic ovariectomy in horses with use of Endoloop ligatures. Vet Surg 6, 478-83.

Davis, E.W. (1997): Laparoscopic cryptoridectomy in standing horses. Vet. Surg. 26, 326-331.

Dijk P., D.P.K. Lankveld, A.B.M. Rijkenhuizen and F.H. Jonker (in press): Hormonal, metabolic and physiological effects of laparoscopic surgery under a sedative analgesic combination of detomidine and buphrenorphine in standing equines. Veterinary anaesthesia and analgesia.

Edwards R.B., N.G. Ducharme and R.P. Hackett (1995): Laparoscopic repair of a bladder rupture in a foal. Vet Surg. 24, 60-3.

Fischer A.T. Jr., K.C. Kent Lloyd, G.P. Carlson and J.E. Madigan (1986): Diagnostic laparoscopy in the horse. JAVMA, 189, 289-292.

Fischer A.T. Jr. (1991): Standing laparoscopic surgery. Vet Clin North Am Equine Pract 7, 641-647.

Fischer A.T. Jr. and A.M. Vachon (1992): Laparoscopic cryptorchidectomy in horses. J Am Vet Med Assoc 201, 1705-1708

Fischer A.T., A.M. Vachon and S.R. Klein (1995): Laparoscopic inguinal herniorrhaphy in two stallions. J Am Vet Med Assoc. 207, 1599601.

Fischer A.T. and A.M. Vachon(1998) Laparoscopic intra-abdominal ligation and removal of cryptorchid testes in horses. Equine Vet J 30, 105-108.
Fischer A.T. Jr. (1999): Laparoscopically assisted resection of umbilical structures in foals. J Am Vet Med Assoc 214, 1813-18166, 17911792.

Galuppo L.D., J.R. Snijder and J.R. Pascoe (1995): Laparoscopic anatomy of the equine abdomen. AJVR, 56, 518-531.

Galuppo L.D., J.R. Snijder, J.R. Pascoe, A.T. Fischer Jr. and R. Morgan (1996): Laparoscopic anatomy of the abdomen in dorsally recumbent horses. Am. J. Vet. Res., 57, 923-931.

Göbel H. und M. Koene (1995): Laparoskopische Untersuchung beim Pferd. Der praktische Tierarzt 5, 447-452.

Gottschalk R.D. and S.S. van den Berg (1997): Standing laparoscopically-aided ovariectomy in mares. J. S. Afr. Vet. Assoc. 68, 102104.

Hanson C.A. and L.D. Galuppo (1999): Bilateral laparoscopic ovariectomy in standing mares: 22 cases. Vet Surg. 28, 106-112.

Hendrickson D.A. and D.G. Wilson (1997): Laparoscopic cryptorchid castration in standing horses. Vet Surg 26, 335-339.

Jones B.D. (1990): Laparoscopy. Veterinary clinics of North America 20, 1243-1263.

Klohnen A. and D.G. Wilson (1996): Laparoscopic repair of scrotal hernia in two foals. Vet Surg 25, 414-416.

Mcllwraith C.W. (1984): Experiences in diagnostic and surgical arthroscopy in the horse. Equine Vet J 16, 11-19.

Palmer S.E. (1993): Standing laparoscopic laser technique for ovariectomy in five mares. J Am Vet Med Assoc. 203, 279-283.

Plaus W.J. (1993): Laparoscopic trocar site hernias. J. Laparoendosc. Surg., 567-570.

Ragle C.A., L.L. Southwood, S.A. Hopper and P.L. Buote (1996): Laparoscopic ovariectomy in two horses with granulosa cell tumors. J. Am. Med. Assoc. 15, 1121-1124.

Ragle CA, L.L. Southwood, L.D. Galuppo and M.R. Howlett (1997): Laparoscopic diagnosis of ischemic necrosis of the descending colon after rectal prolapse and rupture of the mesocolon in two postpartum mares. J Am Vet Med Assoc. 210, 1646-1648.

Ragle C.A., L.L.Southwood and R.K. Schneider (1998): Injury to abdominal wall vessels during laparoscopy in three horses. J Am Vet Med Assoc 1, 87-89.

Ragle C.A., L.L. Southwood and M.R. Howlet (1998): Ventral abdominal approach for laparoscopic cryptorchidectomy in horses. Vet Surg 27, 138-142.

Rijkenhuizen Astrid B.M. (1999): Castration of the stallion: preferably in the standing horse by laparoscopic techniques? Pferdeheilkunde 16, 425-429.

Rijkenhuizen Astrid B.M. (2001): Treatment of haemorrhage after castration by laparoscopic ligation of the spermatic cord in two horses. EVE in press.

Rutgers L.J. and Merkens (1983): Experiences with half-closed castration in stallions. Tijdschr Diergeneeskd. 108, 705-711.

Trostle S.S., N.A. White, L. Donaldson, L.J. Freeman and D.A. Hendrickson (1996): Laparoscopic colopexy in horses. Vet Surg, 56-63.

Trotter G.W. and C.W. Mcllwraith (1996): Advances in equine arthroscopy. Vet Clin North Am Equine Pract. 12, 261-281.

Tulandi T. (1997): How can we avoid adhesions after laparoscopic surgery? [Review article] Current Opinion in Obstetrics and Gynecology, 9, 239-243.

Walmsley J.P. (1999): Review of equine laparoscopy and an analysis of 158 laparoscopies in the horse. Equine Vet J. 31, 456-64. Review.

Wilson D.G., D.A. Hendrickson, A.J. Cooley and E. Degrave-Madigan (1996): Laparoscopic methods for castration of equids. J. Am. Vet. Med. Assoc. 209, 112-114.

Astrid B.M. Rijkenhuizen PhD, dipl. ECVS, dipl. RNVA,

P. van Dijk, PhD, dipl. ECVA

Equine Science

Yalelaan 12

NL-3584 CM Utrecht

e-mail: a.rijkenhuizen@vet.uu.nl 